\title{
Rentasset: A two Tier E Commerce Platform to Rent Product and Services
}

\author{
Sameeran Chaudhari, Harshada Belsare, Pratiksha Mandlik, Nikita Andhale
}

Student, MET Bhujbal Knowledge City, Nashik, Maharashtra, India

\begin{abstract}
How to cite this paper: Sameeran Chaudhari | Harshada Belsare | Pratiksha Mandlik | Nikita Andhale "Rentasset: A two Tier E Commerce Platform to Rent Product and Services" Published in International Journal of Trend in Scientific Research and Development (ijtsrd), ISSN: 24566470, Volume-3 | Issue-4, June 2019, pp.662-664, URL: https://www.ijtsrd.c om/papers/ijtsrd23 894.pdf

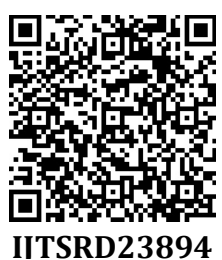

Copyright (C) 2019 by author(s) and International Journal of Trend in Scientific Research and Development Journal. This is an Open Access article distributed under the terms of the Creative Commons

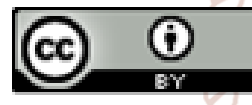
Attribution License (CC BY 4.0) (http://creativecommons.org/licenses/ by/4.

\section{ABSTRACT}

In this we have developed a java based application named "Rentasset" which act as intermediate between the user as well as the vendor to provide the daily essential product online on a very basic rent and also the maintenance services on the online application with in a touch on the screen of our mobile phones. Also this application uses the deposit system for the security of the product listed on the application by the vendor. Payment gateway for online payment provide an ease for the payment option in the application with a cart option available in the application.

\section{INTRODUCTION}

In day to day life we need many product which may be needed by any individual from basic home tool to the various decoration or any thing which cannot be easily available by the individual. Also we need many services which are not easily available in the locality hence to overcome such type of the problems we have developed a system which target on this two major problem. Basically it is based on the E commerce platform.

\section{Basic Concept}

1. Collect customer data for email marketing.

2. Reach new prospective customer through search engine.

3. Increase visibility of shop promotion.

4. Allow customer to shop; where, how and what they want.

\section{Project Plan}

\begin{tabular}{|c|c|c|c|c|c|c|}
\hline T.SSK & MULY & AtGGST & SF.PTEMREER : & NOVEMAER & JANE ARY & ALARCH \\
\hline $\begin{array}{l}\text { Prejert } \\
\text { defnitise } \\
\text { stana }\end{array}$ & & & & & & \\
\hline $\begin{array}{l}\text { Litereser } \\
\text { survey }\end{array}$ & & & & & & \\
\hline Preseaniont & & & & & & \\
\hline Systen desiga & & & & & & \\
\hline Implersentation & & & & & & \\
\hline Implenntation & & & & & & \\
\hline $\begin{array}{l}\text { Depleywater \& } \\
\text { Bepoet }\end{array}$ & & & & & & \\
\hline
\end{tabular}

Testing: test plan and test cases

\section{Software Testing}

Unit Testing

Unit testing, also known as component testing refers to tests that verify the functionality of a specific section of code, usually at the function level. In an object-oriented environment, this is usually at the class level, and the minimal unit tests include the constructors and destructors. These types of tests are usually written by developers as they work on code (white-box style), to ensure that the specific function is working as expected. One function might have multiple tests, to catch corner cases or other branches in the code. Unit testing alone cannot verify the functionality of a piece of software, but rather is used to assure that the building blocks the software uses work independently of each other.

\section{Integration Testing}

Integration testing is any type of software testing that seeks to verify the interfaces between components against a software design. Software components may be integrated in an iterative way or all together. Normally the former is considered a better practice since it allows interface issues to be localised more quickly and fixed. Integration testing works to expose defects in the interfaces and interaction between integrated components (modules). Progressively larger groups of tested software components corresponding to elements of the architectural design are integrated and tested until the software works as a system.

\section{Validation Testing}

The process of evaluating software during the development process or at the end of the development process to determine whether it satisfies specified business requirements.

Validation Testing ensures that the product actually meets the client's needs. It can also be defined as to demonstrate that the product fulfills its intended use when deployed on appropriate environment. 
International Journal of Trend in Scientific Research and Development (IJTSRD) @ www.ijtsrd.com eISSN: 2456-6470

Test Cases and Test Results

\begin{tabular}{|c|c|c|c|c|c|}
\hline $5 \mathrm{r} N 9$ & Description & Input & Expected Result & Actual Result & Ststus \\
\hline f. & $\begin{array}{l}\text { Android } \\
\text { application is } \\
\text { version. }\end{array}$ & Android APP & $\begin{array}{l}\text { Application should } \\
\text { open an android } \\
\text { mobile. }\end{array}$ & $\begin{array}{l}\text { Application is } \\
\text { opening on } \\
\text { android mobile. }\end{array}$ & pass \\
\hline 2. & Vendor login. & $\begin{array}{l}\text { Vendor } \\
\text { Details }\end{array}$ & $\begin{array}{l}\text { System should accept } \\
\text { proper ve ndor details }\end{array}$ & $\begin{array}{l}\text { System is } \\
\text { accepting proper } \\
\text { vendor details }\end{array}$ & pass \\
\hline 3. & $\begin{array}{l}\text { View Product// } \\
\text { Service Detalls }\end{array}$ & $\begin{array}{l}\text { Product// } \\
\text { services }\end{array}$ & $\begin{array}{l}\text { System should able } \\
\text { to view product and } \\
\text { services details }\end{array}$ & $\begin{array}{l}\text { System is able to } \\
\text { vew produxt and } \\
\text { sefvices details }\end{array}$ & pass \\
\hline 4 & $\begin{array}{l}\text { Cart } \\
\text { Generstion }\end{array}$ & $\begin{array}{l}\text { Procuat } \\
\text { details }\end{array}$ & $\begin{array}{l}\text { System should able } \\
\text { to generate cart of } \\
\text { products }\end{array}$ & $\begin{array}{l}\text { System is able to } \\
\text { generate cart of } \\
\text { products }\end{array}$ & pass \\
\hline 5. & $\begin{array}{l}\text { Payment } \\
\text { Gatewsy }\end{array}$ & Product list & $\begin{array}{l}\text { System should } \\
\text { intcgrate with } \\
\text { payment gateway } \\
\text { with list of products }\end{array}$ & $\begin{array}{l}\text { System ib } \\
\text { intcgrating with } \\
\text { payment gateway } \\
\text { with list of } \\
\text { products }\end{array}$ & pass \\
\hline
\end{tabular}

\section{Implementation details}

Firstly system will provide a vendor an customer to register on system.

Vendor can add products which he want to sell or provide on rent. Vendor can modify details of product To propose an system which will allow vendor to provide services for product, And also to provide tools and devices on Rent which are not been worth purchased by any person in day to day life.

Our system will provide a bidding facility both for vendor and also for user. Providing scheduling and rescheduling facility service to customer. Vend or can add their disclaimer points while uploading their product and services to avoid disputes.

\section{Snapshot}

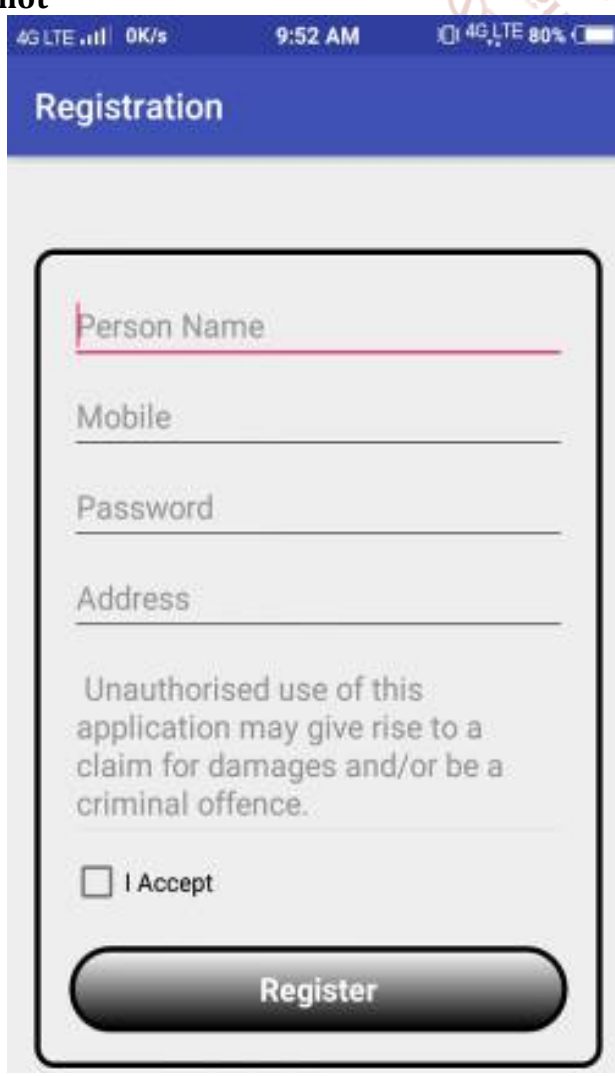

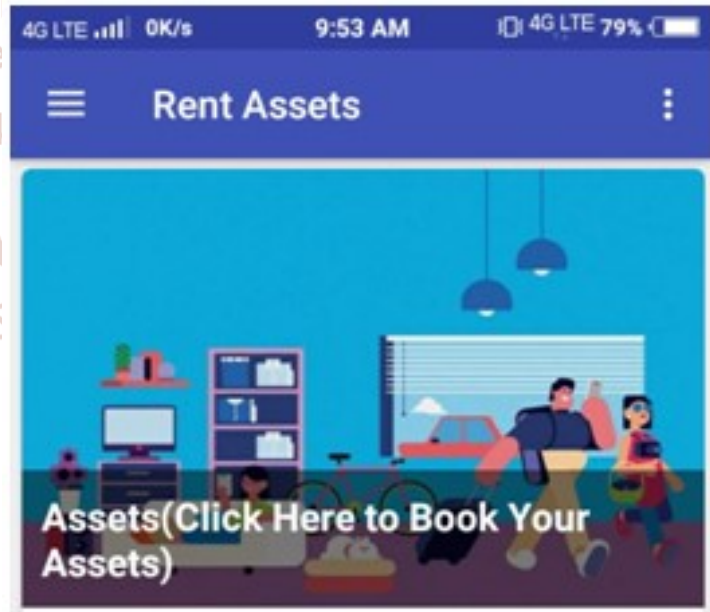

Assets On Rent

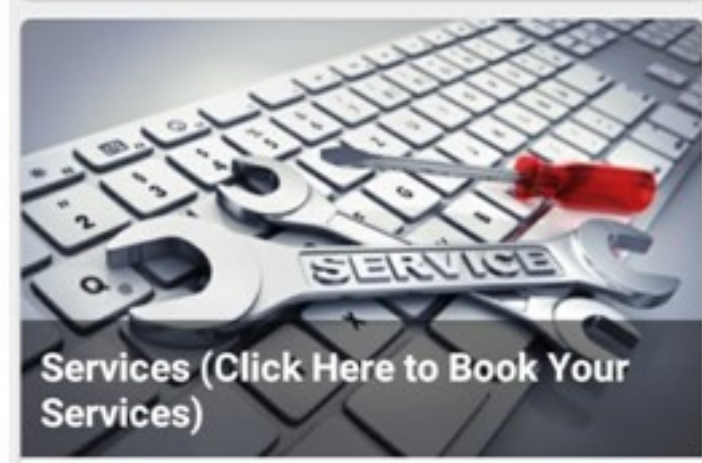

Serices 
International Journal of Trend in Scientific Research and Development (IJTSRD) @ www.ijtsrd.com eISSN: 2456-6470

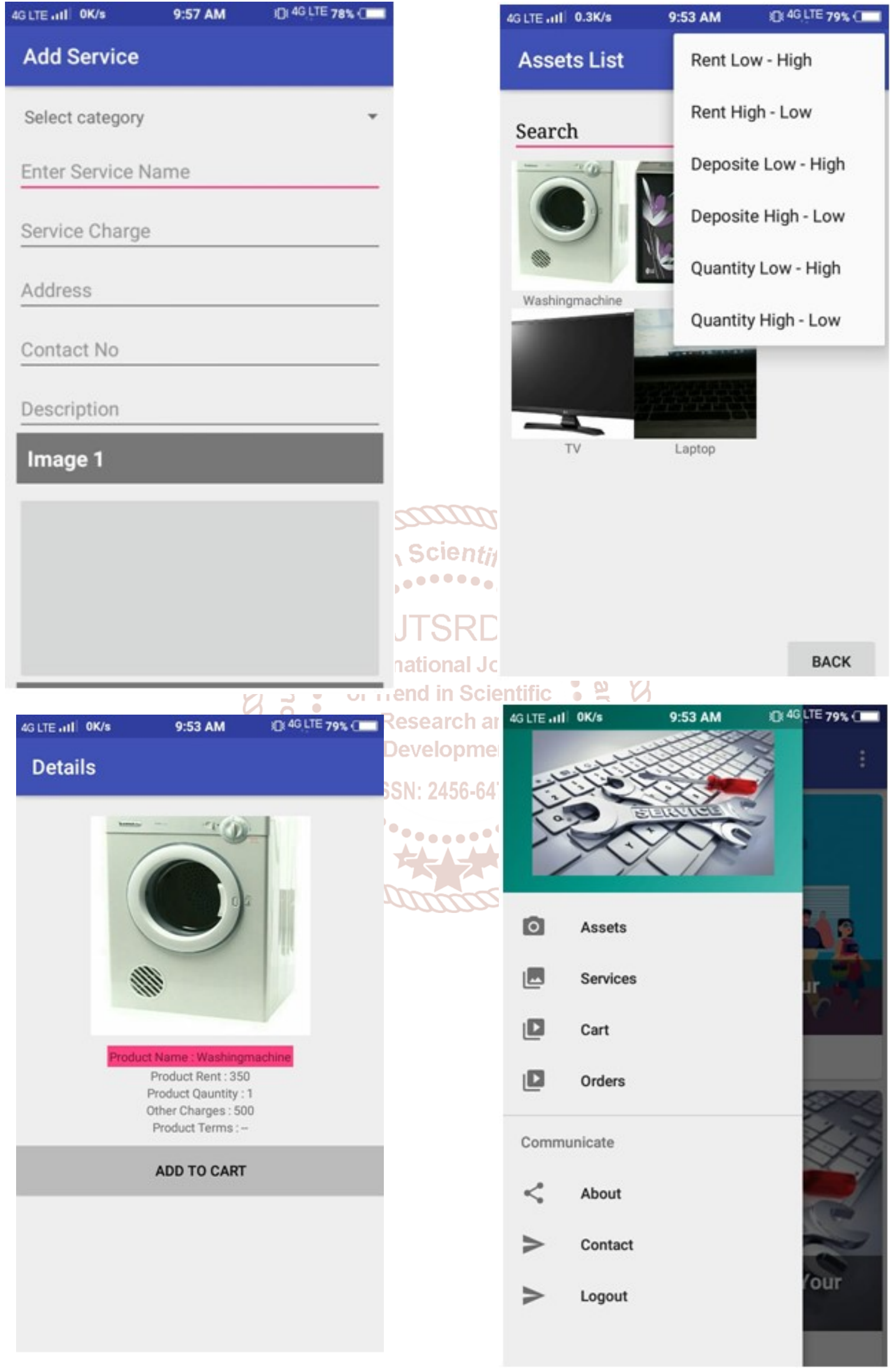

